\title{
Inter-intraspecific variation of chloroplast DNA of European Plantago spp.
}

\author{
NORA HOOGLANDER $\ddagger * \dagger$, ROSELYNE LUMARET* \& MARTEN BOS $\dagger$ \\ *Department of Population Biology, CEFE Centre Louis Emberger, Montpellier, France, and tDepartment of Genetics, \\ University of Groningen, The Netherlands
}

\begin{abstract}
Inter- and intraspecific chloroplast DNA variation in four species of Plantago ( $P$. lanceolata, $P$. major, $P$. media and $P$. coronopus) were analysed by comparing DNA fragment patterns produced by seven restriction endonucleases. Plant material was collected in seven European countries. Only 21.3 per cent of the 409 restriction sites were shared by all four species. Phylogenetic analysis, performed by constructing the most parsimonious trees, showed that genetic differentiation in cpDNA was very high among $P$. lanceolata, $P$. coronopus and the species pair $P$. media and $P$. major, which were more closely related.

At the intraspecific level, four restricted site mutations were detected. Most of the variation was due to numerous small length mutations, one of which $(70 \mathrm{bp})$ discriminated between the two subspecies of $P$. major (i.e. ssp. major and ssp. pleiosperma). This mutation was used successfully to show that, in Denmark, cpDNA introgression occurs from pleiosperma into major in the areas where the two subspecies grow together, whereas previous studies of the same subspecies in the Netherlands suggested introgression in the reverse direction. In P. lanceolata, five distinct types of cpDNA genome could be distinguished, one of these being widely distributed. Therefore, DNA variation was present both between and within populations. In P. media, three distinct cpDNA genomes were found, one being specific to diploid and tetraploid material from the Pyrenees, suggesting multiple origins of the autotetraploids in this species.

Whereas cpDNA variation was observed in the two outcrossing species of Plantago ( $P$. media and $P$. lanceolata) no variation was detected in the two autogamous subspecies of $P$. major. This suggests that chloroplast DNA variation may be related to nuclear genome diversity.
\end{abstract}

Keywords: autopolyploidy, breeding system, cpDNA variation, Plantago, RFLP.

\section{Introduction}

Comparison of chloroplast DNA (cpDNA) restriction fragment length polymorphism (RFLP) has proved to be a very useful tool to study evolutionary processes at and above the species level (Palmer, 1986, 1987 and references therein; Lehväslaiho et al., 1987; Sandbrink et al., 1989; Pillay \& Hilu, 1990; Soreng, 1990). However, the use of this approach to analyse population structure and speciation processes has long been considered to be unsuitable because of the conservative nature of cpDNA (Palmer, 1987). Among the studies of intraspecific cpDNA variation reviewed by

Correspondence: Dr Roselyne Lumaret, Centre Emberger, CNRS, Route de Mende, BP 5051, 34033 Montpellier Cedex, France. $\ddagger$ Present address: Department of Plant Breeding, Wageningen Agricultural University, P.O. Box 3866700 , AJ Wageningen, The Netherlands.
Harris \& Ingram (1991), several have reported low levels of variability (e.g. Timothy et al., 1979; Clegg et al., 1984; Banks \& Birky, 1985; Doebley et al., 1987; Sandbrink et al., 1990). Other recent studies have shown, however, that RFLP analysis of cpDNA can provide valuable information on evolutionary processes, even at the population level (e.g. Sytsma \& Schaal, 1985; Lumaret et al., 1989; Soltis et al., 1989a, b; Wolf et al., 1990).

The use of cpDNA as a marker, alone or combined with nuclear genome markers such as enzyme polymorphism, has nevertheless proved to be a powerful tool for examining phylogenetic relationships between diploids and polyploids in intraspecific polyploid complexes and/or to document patterns of introgression among populations (e.g. Lumaret et al., 1989). In addition, the influence of cpDNA variation on malesterility, and thus the control of sex-polymorphism, has 
been suggested in several studies (e.g. Galau \& Wilkins, 1989; Chen et al., 1990).

In the present study, cpDNA variation has been analysed between and within populations distributed over seven European countries, among four species of Plantago: P. lanceolata L., P. major L., P. media L., P. coronopus L. These species possess a Eurasian primary distribution and have already been the subject of extensive research at both the inter- and intraspecific levels, which has revealed a wide range of variation for biological characteristics and evolutionary strategies. Many studies have examined the geographical distributions at both the species and the cytotype level (e.g. Rahn, 1954, 1957; Sagar \& Harper, 1964; Van Dijk \& Hartog, 1988), breeding system variation (e.g. Ross, 1970, 1973; Bos et al., 1985; Van Damme, 1983, 1986; Van Damme \& Van Delden, 1982, 1984; Rouwendal et al., 1987 Wolff et al., 1988) and also the relationship between breeding system and genetic structure, as observed from enzyme polymorphism and/or morphological variation (e.g. Van Dijk, 1984, 1985; Van Dijk et al., 1988; Wolff, 1988). In other studies, variation for several life-history traits (e.g. Antonovics \& Primack, 1982; Alexander \& Wulff, 1985; Van Groenendael, 1986) and the relationship between genetic variability and environmental conditions (e.g. Van Dijk \& Van Delden, 1981; Van Dijk, 1984; Van Dijk et al., 1988) have also been examined. These studies have shown that population genetic differentiation is high in the inbreeding species $P$. major and low in the self-incompatible, gynodioeceous species, having an intermediate level of variation (Van Dijk et al., 1988). The species $P$. major comprises two subspecies, major and pleiosperma PILGER, which exhibit distinct morphological traits (Engler, 1937). Moreover, the subspecies show ecological differences and subspecies-specific alleles at two enzyme loci, although transitional forms and gene flow have also been observed in several sites of sympatry (Van Dijk \& Van Delden, 1981). In Plantago media, the tetraploids are morphologically very similar to the diploids with which they can coexist in contact areas. The two cytotypes show a postzygotic reproductive isolation, but share the same alleles for nine allozyme loci, providing evidence for the autopolyploid origin of the tetraploid (Van Dijk \& Van Delden, 1990).

Wolff \& Schaal (1992) have recently reported a high amount of intra- and interspecific cpDNA variation in Plantago spp. by studying Dutch and American populations of $P$. major and $P$. lanceolata, Dutch populations of $P$. coronopus and $P$. maritima, and two Spanish populations of $P$. media. The two subspecies of $P$. major were discriminated by distinct restriction patterns, although plants showing intermediate patterns were observed in both the U.S.A. and in The Netherlands. In their study, Wolff \& Schaal (1992) used total DNA, hybridized with cpDNA probes from Petunia and cut with restriction enzymes, thus providing an estimated 86 per cent survey of the chloroplast genome.

The present study was based on isolation of the whole cpDNA molecule before cutting it with restriction enzymes. The objectives were as follows: (i) to estimate cpDNA size and thus genome variation, among and within the four cosmopolitan Plantago species in Europe; (ii) to compare the variation in the cytoplasmic genome with that of the nuclear genome studied previously by enzyme polymorphism, in relation to the biological characteristics (in particular the breeding system) of the four species; (iii) to seek further evidence for both differences in the cpDNA structure of the two subspecies of $P$. major, and introgression in an additional contact area in Denmark; and (iv) to provide a decisive test of the hypothesis of an autopolyploid origin of tetraploid $P$. media.

\section{Materials and methods}

\section{Origins of plant material}

Chloroplast DNA analyses were carried out on 48 individual plants from natural populations of four Plantago species (Table 1). Species identification was according to the Flora Europaea (Tutin \& Webb, 1976). Most of the plant material analysed in this study has been used previously in extensive interdisciplinary studies and voucher material can be examined in the laboratories of Groningen and Montpellier. Details regarding several of the collecting sites have already been published by Van Dijk \& Van Delden (1981), Van Dijk (1984) and Van Dijk et al. (1988) for populations 3, 6, 7, 10, 11, and 20; by Van Dijk \& Hartog (1988) and by Van Dijk \& Van Delden (1990) for populations 15,16 and 19. Populations 1 and 14 came from the same collecting site in the experimental field of the laboratory in Montpellier (South of France). Population 2 was sampled from the botanical garden of the University of Groningen in Haren (The Netherlands). Population 4 corresponded to a strand in Öland Island (Sweden) and population 5 was from an old pasture with dry sandy soil near Warsaw (Poland). Plants of $P$. major in population 8 and 13 belonged to subsp. pleiosperma and subsp. major respectively and were collected from wet and dry parts of the same site, alongside a barley field near Roskilde (Denmark). The collecting site corresponding to population 9, a wet area in an agricultural field with plants belonging only to subsp. pleiosperma, was located in the same region as popula- 
Table 1 Origin of the 48 studied plants of four species of Plantago and the cases where RFLP analyses were performed $(+)$ for seven enzymes

\begin{tabular}{|c|c|c|c|c|c|c|c|c|}
\hline \multirow[b]{2}{*}{ Origin } & \multirow{2}{*}{$\begin{array}{l}\text { Sampled } \\
\text { plant }\end{array}$} & \multicolumn{7}{|c|}{ Restriction enzymes } \\
\hline & & AvaI & $B g l \mathrm{II}$ & Bst $\mathrm{I}$ & EcoRI & HincII & HindIII & $P v u I I$ \\
\hline \multicolumn{9}{|l|}{ P. lanceolata } \\
\hline 1 Montpellier (F) & 9 & + & + & + & + & + & + & + \\
\hline $2 \operatorname{Haren}(\mathrm{NL})$ & 2 & + & + & + & + & + & + & + \\
\hline 3 Westduinen (NL) & 2 & + & + & + & + & + & + & - \\
\hline 4 Öland (P42) (SU) & 2 & + & + & - & + & + & + & - \\
\hline 5 Warsaw $(\mathrm{P} 45)(\mathrm{PL})$ & 2 & + & + & + & + & + & + & - \\
\hline \multicolumn{9}{|l|}{ P. major subsp. pleiosperma } \\
\hline 6 Zwolle $(\mathrm{Z} 2)(\mathrm{NL})$ & 1 & - & - & + & - & - & - & - \\
\hline 7 Arnhem (A2)(NL) & 1 & + & + & + & + & - & + & + \\
\hline 8 Roskilde 3b (DK) & 4 & - & + & + & + & - & - & - \\
\hline 9 Roskilde 5 (DK) & 4 & - & + & + & + & - & - & - \\
\hline \multicolumn{9}{|l|}{ P. major subsp. major } \\
\hline 10 Groningen $\mathrm{G} 1(\mathrm{NL})$ & 1 & - & + & + & + & - & - & - \\
\hline 11 Groningen $\mathrm{G} 7(\mathrm{NL})$ & 1 & - & - & + & + & - & - & - \\
\hline $12-(\mathrm{NL})$ & 1 & + & + & + & + & - & + & - \\
\hline 13 Roskilde 3a(DK) & 3 & - & + & + & + & - & - & - \\
\hline 14 Montpellier $(\mathrm{F})$ & 4 & - & + & + & + & - & - & - \\
\hline \multicolumn{9}{|l|}{ P. media $(4 \times)$} \\
\hline 15 Westervoort (NL) & 3 & - & + & + & + & - & - & - \\
\hline 16 Formigal (SP) & 2 & - & + & + & + & - & + & - \\
\hline 17 Jalta $\mathrm{Me} 17$ (CR) & 1 & - & + & - & + & - & - & - \\
\hline 18 Szklary Me19(PL) & 1 & - & + & - & + & - & - & - \\
\hline \multicolumn{9}{|l|}{ P. media $(2 \times)$} \\
\hline 19 Gavarnie $(F)$ & 2 & - & + & + & + & - & + & - \\
\hline \multicolumn{9}{|l|}{ P. coronopus } \\
\hline 20 Schiermonnikoog $(\mathrm{NL})$ & 2 & - & + & - & + & - & - & + \\
\hline
\end{tabular}

$\mathrm{DK}=$ Denmark $; \mathrm{F}=$ France $\mathrm{NL}=$ the Netherlands $\mathrm{PL}=$ Poland $\mathrm{SP}=\mathrm{Spain} ; \mathrm{SU}=$ Sweden $; \mathrm{CR}=$ Crimea.

tions 8 and 13. The precise origin of 12 , in The Netherlands, is unknown.

In most cases, seeds from identified mother plants, collected in the natural sites, were grown in uniform conditions in a greenhouse for 2 months prior to analysis. For populations 1 and 14, adult plants were collected directly and grown in the greenhouse for 1 month under the same conditions as plants from the other sites.

\section{Preparation and restriction endonuclease analysis of cPDNA}

The plants were placed in the dark for $14 \mathrm{~h}$ to destarch the leaves before the leaf tissue was harvested. The leaves were then ground by hand in liquid nitrogen and freeze-dried. Chloroplasts were isolated from aliquots of $2 \mathrm{~g}$ of the freeze-dried leaf powder using a nonaqueous procedure as described by Dally \& Second (1989) with the following modifications: as step 4 the density of the cold mixture ranged from 1.38 to 1.40 according to the studied species. At step 9, $100 \mathrm{l}$ of pronase $(10 \mathrm{mg} / \mathrm{ml})$ and $250 \mathrm{l}$ Sarkosyl (20 per cent) were added instead of proteinase $\mathrm{K}$ and the mixture was incubated at $37^{\circ} \mathrm{C}$ for $1 \mathrm{~h}$. At step $10,200 \mathrm{l}$ of $3 \mathrm{M}$ $\mathrm{Na}$, acetate buffer, pH 6.0, was used. At step 11, 201 magnesium chloride $(1 \mathrm{M})$ was added to the mixture before ethanol-precipitation of DNA in $15 \mathrm{ml}$ siliconed tubes. The pellet was ethanol-washed three times and dissolved in $501 \mathrm{TE}$ buffer.

Aliquots of $20 \mu \mathrm{g}$ total chloroplast DNA were incubated with the restriction endonucleases listed in Table 1 , according to the recommendations of the suppliers (Appligène, Boeringer, Germany) and in the presence 
of $4 \mu \mathrm{g}$ pancreatic A ribonuclease. In Plantago, the restriction enzyme BstI behaved as a perfect isoschizomer of BamHI. The digestion products were fractioned by electrophoresis on horizontal $0.8,1.0,1.1$, or 1.3 per cent agarose slab gels, depending on the number of fragments generated by the enzyme. Several agarose concentrations were used for the same enzyme in order to separate clearly large and small fragments. Gels were stained with ethidium bromide and photographed under ultraviolet light. Lambda DNA digested with HindIII, EcoRI, and with both these enzymes was used as size standards.

\section{Data analysis}

The cpDNA restriction endonuclease patterns of the individual plants were scored for fragment length differences. This method has been advocated when the cpDNA sequences have diverged to the extent that direct restriction site mutation analysis cannot be used (Sandbrink \& Van Brederode, 1992a). For each species, the most frequent and ubiquitous pattern that occurred in several distinct geographical areas was considered as representative of the species. Phylogenetic data analysis was reserved for phylogenetically informative cases, i.e. where restriction fragments were shared by at least two, but not all, the taxa. The different fragments obtained using the different enzymes were scored as presence/absence data, and pooled to compute a similarity matrix using the method of Nei \& Li (1979) adapted to fragment analysis instead of restriction sites. The fraction of shared fragments was estimated by $F=2 N_{\mathrm{xy}} /\left(N_{\mathrm{x}}+N_{\mathrm{y}}\right)$ where $N_{\mathrm{xy}}$ is the number of bands taxon $\mathrm{x}$ and taxon $\mathrm{y}$ have in common, and $N_{\mathrm{x}}$ and $N_{\mathrm{y}}$ are the number of bands found for taxon $\mathrm{x}$ and $\mathrm{y}$ respectively. Each similarity matrix ( $F$ values) was then analysed by the UPGMA method using the NTSYs computer program. In addition, the DNA changes were scored as presence/absence data and analysed cladistically by enumeration of all most parsimonious unrooted trees using Wagner's parsimony method (MIX option of PHYLIP 3.0, Felsenstein, 1987) because no outgroup species was available. Moreover, the воOт option of PHYLIP was used to place confidence intervals on monophyletic groups (Felsenstein, 1985).

\section{Results}

When cpDNA from the 48 individuals listed in Table 1 was analysed by digestion with the seven different restriction endonucleases, 39 different banding patterns were observed giving a total of 1590 fragments, 409 of which were distinct from one another. Most of these banding patterns are illustrated in Figs
1-3. The restriction endonucleases $A v a \mathrm{I}, B g l \mathrm{II}, B s t \mathbf{I}$, EcoRI, HincII, HindIII and PvuII generated an average of $48.16,45.09,36.20,47.50,51.25,23.50$ and 13.33 fragments respectively. Thirty-one per cent of the individuals were analysed on at least two gels per enzyme and no variation was observed among the replicated samples.

Chloroplast DNA molecular size was estimated by adding together the size of the fragments generated by each endonuclease, particularly those generated by $P v u I I$ which provided fewer and larger sized fragments. The molecular size of cpDNA in Plantago was estimated to be between 135 and $142 \mathrm{~kb}$ in $P$. lanceolata, 135 and $139 \mathrm{~kb}$ in $P$. major (subsp. major and pleiosperma), 130 and $135 \mathrm{~kb}$ in P. media and 142 and $145 \mathrm{~kb}$ in $P$. coronopus. The proportion of shared fragments by all four species was 21.3 and 20.1 per cent for EcoRI and BglII respectively (Figs 2 and 3 ) and the proportion of fragments shared by $P$. lanceolata, $P$. major and $P$. media was 32.4, 24.4, 19.4 and 43.5 per cent for EcoRI, BglII, BstI and HindIII respectively.

The percentages of shared fragments ( $F$-values) calculated from these data are presented in Table 2. The fraction of shared fragments decreased from 97.3 per cent for the two subspecies of $P$. major, to 25.8 per cent between $P$. coronopus and $P$. major (Table 2, lower left).

When the similarity matrix 1 was subject to UPGMA analysis, three distinct groups of species could be distinguished (Fig. 4a). The first cluster included $P$. major (subsp. major and subsp. pleiosperma) and $P$. media, the second corresponded to $P$. lanceolata and the third to $P$. coronopus. A similar phyletic pattern was observed in the phenogram comprising $P$. lanceolata, $P$. media and $P$. major, when matrix 2 was subject to the same analysis (Fig. 4b). The same general clustering pattern was obtained using the Wagner parsimony method (Fig. 4c and results not shown) applied to the fragment patterns produced by the several restriction enzymes analysed individually. For $B g l \mathrm{II}$, a single most parsimonious tree of 39 steps was obtained from the 35 phylogenetically informative changes (Fig. 4c). To place confidence intervals on monophyletic groups, 100 bootstrap cycles were performed using the воот option of PHYLIP. Confidence was 100 per cent for all the clades.

Discrimination between cpDNA of subsp. major and subsp. pleiosperma is due to a 70-bp addition/ deletion. This variation is observed for three restriction enzymes: Bst I (Fig. 2) (a 2.54-kb fragment in subsp. major is replaced by a $2.47-\mathrm{kb}$ fragment in subsp. pleiosperma), BglII (Fig. 2) (a 1.68-kb fragment in subsp. major is replaced by a $1.61-\mathrm{kb}$ fragment in subsp. pleiosperma) and AvaI (Fig. 3) (two fragments, 
Fig. 1 Example of restriction fragment patterns obtained by digestion of cpDNA with Bstl in Plantago lanceolata (A1, A2), P. major subsp. pleiosperma (B1), and subsp. major $(\mathrm{C} 1), P$. media (D1) and with $B g I I I$ in $P$.

lanceolata (A1, A2, A3, A4, A5), P. major subsp. pleiosperma $(\mathrm{B} 1)$ and subsp. major (C1), P. media (D1, D2) and $P$. coronopus (E1). Agarose concentrations in the original gels were 0.8 and 1 per cent using $B s t \mathrm{I}$ and $B g I I \mathrm{I}$ respectively.

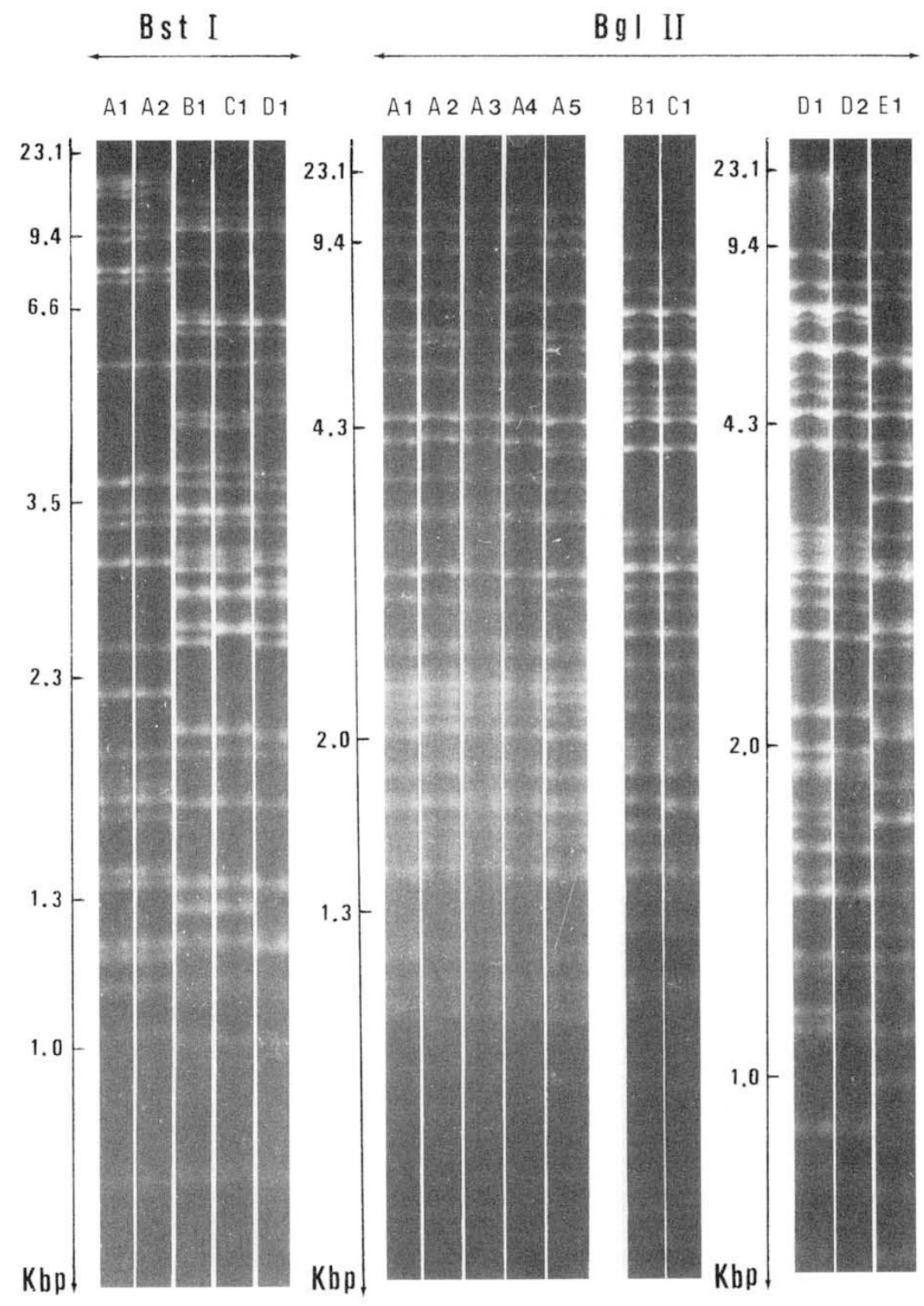

3.31 and $1.92 \mathrm{~kb}$, present in subsp. major are replaced respectively by two fragments, 3.28 and $1.88 \mathrm{~kb}$, in pleiosperma). However, whereas all the nine individuals identified morphologically as subsp. pleiosperma showed the same pattern specific of this subspecies, among the 10 individuals identified as subsp. major, two out of the three collected near Roskilde (Denmark), site 13, where the two subspecies grow together, showed the cpDNA patterns of subsp. pleiosperma.

Apart from the mutation which discriminates between the two subspecies of $P$. major, no variation was found in this species for the 20 individuals collected in eight sites scattered in three countries of western Europe. Likewise, no variation was observed in $P$. coronopus; however, only two individuals collected from the same site were studied in this species.

In $P$. lanceolata, in addition to the majority of restriction patterns designated as 'A1', 3, 1, 4, 2, 1, and 3 distinct variant patterns were observed for $A v a \mathrm{I}$, BstI, BglII, EcoRI, HindIII, and Hincll respectively, totalling 34 distinct mutations. Among these, two types (site and length) could be distinguished according to 


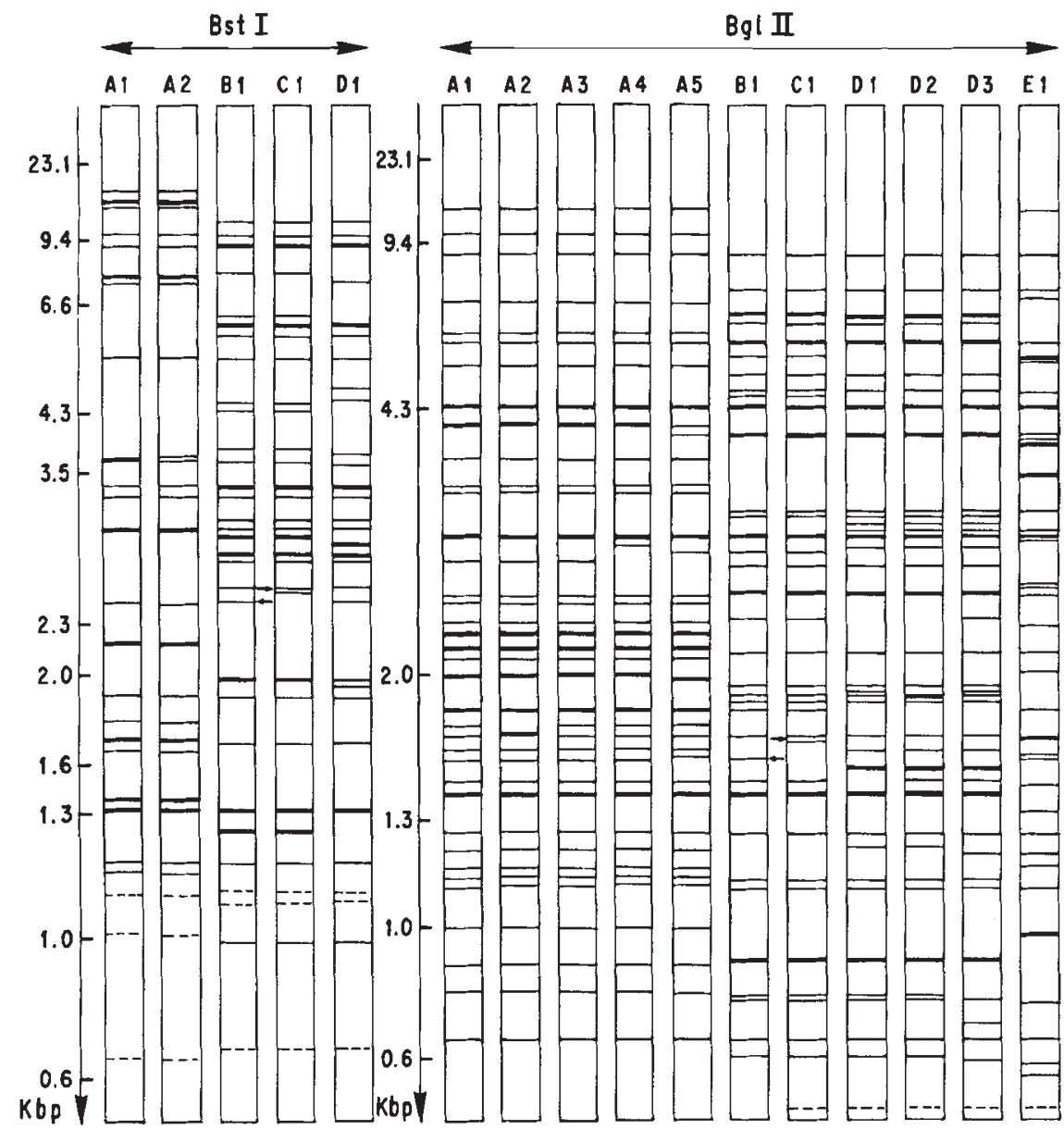

Fig. 2 Diagrammatic representation of restriction fragment patterns obtained by digestion of $\mathrm{cpDNA}$ with $B s t \mathrm{I}$ in Plantago lanceolata (A1, A2), P. major subsp. pleiosperma (B1), P. major subsp. major (C1), P. media (D1) and with $B g / I \mathrm{I}$ in $P$. lanceolata $(\mathrm{A} 1, \mathrm{~A} 2, \mathrm{~A} 3$, A4, A5), P. major subsp. pleiosperma (B1), and subsp. major (C1), P. media (D1, D2, D3) and P. coronopus (E1). High intensity bands indicate the occurrence of two identical fragments. Agarose concentrations of the original gels were 0.8 and 1 per cent using $B s t \mathrm{I}$ and $B g l I I$, respectively. the specific phenotype of the restriction fragment alteration (Table 3). More particularly, the detection of specific changes each revealed by several restriction enzymes, suggests that alterations in the length of the fragments may be due to DNA length rather than site mutations. Finally, four mutations corresponded to site changes and at least 29 were considered as length mutations; few of them were observed using several, but never all, the enzymes (e.g. mutation ' $\mathrm{g}$ ', observed in the same individuals of accession 5 using EcoRI and $H$ incII). Most of these size mutations were very small, ranging from 10 to $100 \mathrm{bp}$. Moreover, in the cpDNA of two individuals from Poland (accession 5), additional changes were observed: two fragments ( 8.80 and 2.50 $\mathrm{kb})$ were observed instead of the 9.00 and $2.30 \mathrm{~kb}$ fragments present in the majority pattern. These changes can be considered as two independent length mutations. However, when they are considered together, they may correspond to an inversion $(9.00+2.30 \mathrm{~kb}$ in the majority pattern are changed into $8.80+2.50 \mathrm{~kb}$ in the restriction patterns of the two Polish individuals). As no HindIII restriction fragments mapping was available to confirm the presence of this inversion, and because such mutations are apparently rare in cpDNA evolution (Palmer, 1987), in the data treatment, cpDNA changes in the two Polish plants were considered as two additional length mutations. In Table 3 , mutations having the same pattern with distinct enzymes are indicated by the same letter. By scoring them arbitrarily as the same, we avoided counting the same deletion several times and, therefore, overestimating the number of distinct mutations, although this does not completely exclude the possibility that they represent independent mutations.

In Plantago lanceolata, the mutations were: (i) in either a single or a small number of individuals growing at a particular site (e.g. the BstI A2 variant pattern was observed in only one of the nine plants collected in Montpellier), (ii) specific to a particular location (e.g. A3 and A5 BglII variants found in plants collected in Sweden and Poland respectively), (iii) found in individuals from several distant locations (e.g. the mutation ' $b$ ' observed in a single plant from Montpellier and in the two individuals from Warsaw). However, because these two locations are very distant, it is more probable that length mutations of the same size may not be 


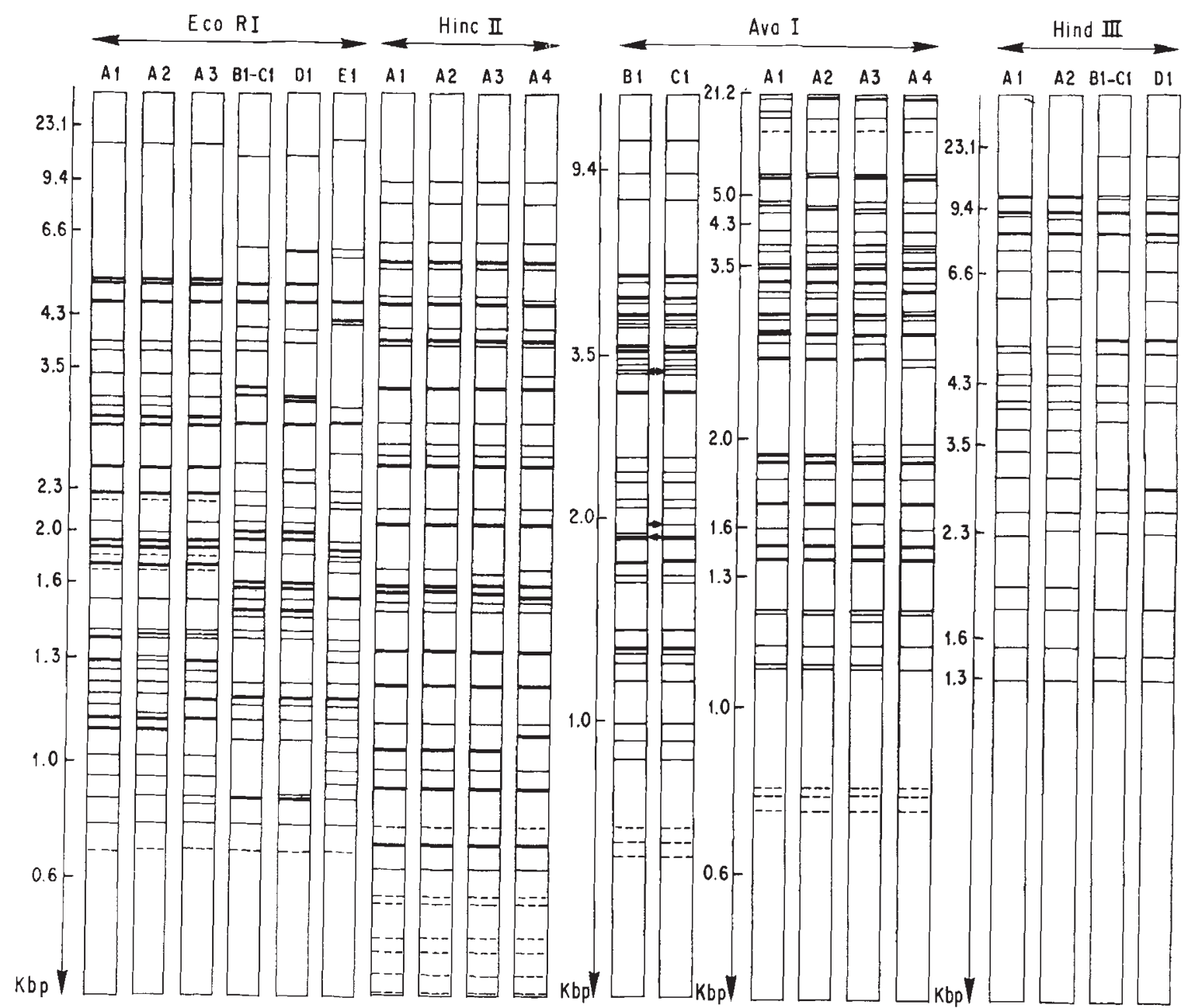

Fig. 3 Diagrammatic representation of the restriction fragment patterns obtained by digestion of cpDNA with EcoRI, HincII, AvaI, and HindIII in Plantago lanceolata (A), P. major subsp. pleiosperma (B), subsp. major (C), P. media (D), and $P$. coronopus (E). High intensity bands indicate the occurrence of two identical fragments. Agarose concentrations in the original gels were 1 per cent using EcoRI, HinclI and AvaI, 1.3 per cent using $A v a \mathrm{I}$ in $P$. lanceolata, and 0.8 per cent using HindIII.

Table 2 Chloroplast DNA data matrix for four species of Plantago (including two subsp. of $P$. major) from EcoRI and $B g$ II RFLPs (lower left) and for three species of Plantago from RFLPs using EcoRI, BglII, BstI and HindIII enzymes (upper right) showing the proportion of shared fragments $(F$-values, \% $)$

\begin{tabular}{lllll}
\hline & 1 & 2 & 3 & 4 \\
\hline 1 P. lanceolata & - & 33.0 & 33.0 & 33.7 \\
2 P. major ssp. pleio. & 33.1 & - & 98.0 & 81.8 \\
3 P. major ssp. major & 33.1 & 97.3 & - & 81.1 \\
4 P. media & 32.8 & 84.0 & 84.0 & - \\
5 P. coronopus & 27.9 & 25.8 & 25.8 & 26.6 \\
\hline
\end{tabular}

homologous. Finally, when the results were pooled for the six restriction enzymes, for which sufficient data were available, namely $A v a \mathrm{I}, B g l \mathrm{II}, B s t \mathrm{I}$, EcoRI, HinclI and HindIII, all the plants showed the same (majority) pattern (LM genome) except two out of nine individuals from Montpellier ( $\mathrm{Lm} 1$ and $\mathrm{Lm} 2$ minority genomes), the individuals collected in Sweden ( $\mathrm{Lm} 3$ ) and in Poland $(\mathrm{Lm} 4)$.

The percentage of shared fragments ( $F$-values) among the five distinct cpDNA genomes observed in $P$. lanceolata (namely LM, Lm1, Lm2, Lm 3 and $\mathrm{Lm} 4$ ) are indicated in Table 4. $F$-values decreased from 99.5 per cent (between two genomes found in Montpellier) to 84.6 per cent (between a cpDNA genome from 


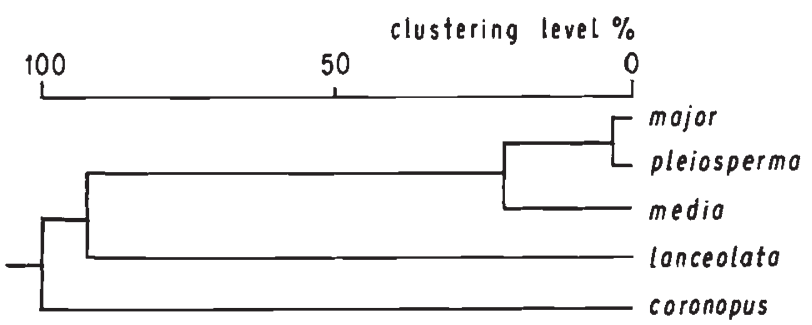

a

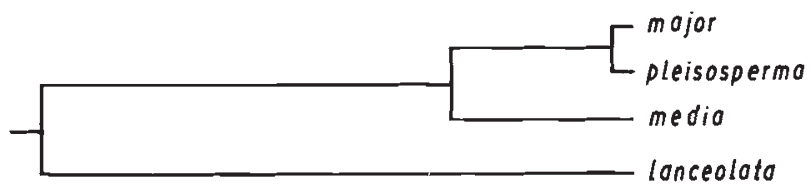

b

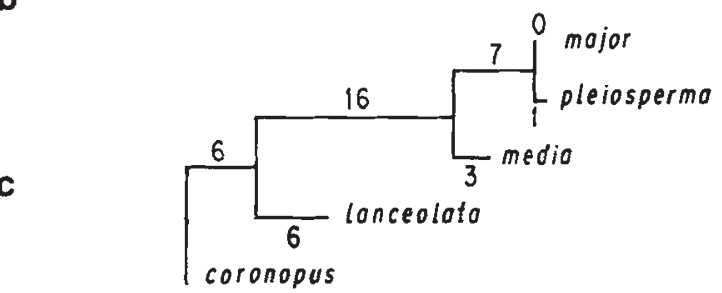

Fig. 4 UPGMA phenograms (based on the proportion of shared fragments) for (a) the four species of Plantago and the two subspecies of $P$. major scored for $E c o$ RI and $B g / \mathrm{II}$ cpDNA RFLPs. (b) P. major (two subspecies), $P$. media and $P$. lanceolata scored for EcoRI, BglII, BstI and HindIII cpDNA RFLPs. (c) Most frequently selected Wagner tree of $P$. major, $P$. media, $P$. lanceolata and $P$. coronopus scored for $B g I I I$ cpDNA RFLPs. Numbers on the branches indicate the minimum number of mutation steps.

Montpellier and one observed in the two individuals from Poland).

When cpDNA from $P$. media was digested with $B g l$ II, six length mutations were revealed and three distinct genomes could be distinguished (Table 3). The D1 genome is observed in plants from Westervoort in the Netherlands and from Szklary in Poland and, therefore, was considered as the majority MM genome; the D2 genome is common to the diploid and the tetraploid plants from the Pyrenees (Mm1 genome) and the D3 genome is observed in tetraploid individuals from the Crimea ( $\mathrm{Mm} 2$ genome). The percentage of shared fragments among these three plastid genomes is shown in Table 4.

\section{Discussion}

\section{Interspecific cpDNA differentiation}

A maximum 15-kb cpDNA size variation was observed between $P$. media and $P$. coronopus which possessed the smallest and the largest molecules respectively. Wolff \& Schaal (1992) have estimated the cpDNA size of $P$. lanceolata to be $144 \mathrm{~kb}$ from a survey of 86 per cent of the molecule and assuming a strict homology with cpDNA from Petunia. This value is slightly higher than that obtained from our study.

Differentiation of cpDNA was observed to be higher among $P$. lanceolata, $P$. coronopus and the species pair $P$. media and $P$. major than between $P$. media and $P$. major which are more closely related. The same general differentiation pattern was obtained by Wolff \& Schaal (1992) from cpDNA digested with numerous restriction enzymes mostly distinct from those used in the present study (only two out of 16 enzymes were common to the two studies). The same differentiation pattern was also obtained for these two species (which belong to distinct Plantago sections) using enzyme polymorphism (E. Boekema \& $\mathrm{H}$. Van Wÿk, unpublished data). Plantago media has been considered to possess several morphological and physiological traits close to either $P$. lanceolata or $P$. major or intermediate between these two species (e.g. Sagar \& Harper, 1964). However, from the results obtained in this study it is clear that, as far as cpDNA variation is concerned, $P$. media is more closely related to $P$. major than to $P$. lanceolata.

In Plantago, cpDNA divergence between several species (except between $P$. major and $P$. media) ranges up to 74.2 per cent as distinct fragments. This is higher than the cpDNA divergence found in the plant genera studied to date (Sandbrink et al., 1989), including Linum and the tropical fern genus Platycerium in which the divergence was very high ( 53 and 59 per cent distinct fragments respectively, Coates \& Cullis, 1987; Sandbrink et al., 1992b). Wolff \& Schaal (1992) found 52 per cent of their restriction sites to be variable among species. Although, in the present study, a complete analysis of the mutations was not possible because of the amount of cpDNA divergence among the Plantago species, it seems that the majority of the changes comprised very small length mutations. Wolff \& Schaal (1992) also reported many length changes in the cpDNA of Plantago. As these changes may have been revealed several times using the different restriction enzymes, such mutations may be responsible for the high cpDNA divergence observed in Plantago.

\section{Chloroplast DNA differentiation between the two subspecies of $\mathrm{P}$. major}

The subsp. major and pleiosperma can be distinguished by morphological characteristics, life-history traits, habitat conditions and by the occurrence, at two enzyme loci, of alleles which are specific for one of the 
Table 3 Restriction fragment length changes $(\mathrm{kb})$ and type of mutation (I: site and II: length) in variant restriction patterns of $P$. lanceolata (A2, A3, A4, A5) compared to the majority pattern (A1) and of $P$. media (D2, D3) compared with the majority pattern (D1). The geographical origin (accession number) and the numbers of plants showing each pattern are also indicated. Indexed with the same letter are changes attributable to the same mutation. The numbers in parentheses indicate that the mutations are likely to involve two fragments

\begin{tabular}{|c|c|c|c|c|c|}
\hline \multirow[b]{2}{*}{ Enzyme } & \multirow{2}{*}{$\begin{array}{l}\text { Restriction } \\
\text { pattern }\end{array}$} & \multicolumn{2}{|l|}{ Mutation type } & \multirow{2}{*}{$\begin{array}{l}\text { Accession } \\
\text { number }\end{array}$} & \multirow{2}{*}{$\begin{array}{l}\text { Plant } \\
\text { number }\end{array}$} \\
\hline & & I & II & & \\
\hline Bst $\mathbf{I}$ & $\mathrm{A} 2$ & - & $3.67 \rightarrow 3.69$ & 1 & 1 \\
\hline \multirow[t]{7}{*}{$B g l I I$} & $\mathrm{~A} 2$ & - & a $\begin{aligned} 2.75 & \rightarrow 2.70 \\
1.76 & \rightarrow 1.73\end{aligned}$ & 1 & 1 \\
\hline & $\mathrm{A} 3$ & - & a $2.75 \rightarrow 2.70$ & 1 & 1 \\
\hline & A4 & - & $2.75 \rightarrow 2.83$ & 4 & 2 \\
\hline & A5 & - & $4.02 \rightarrow 3.93$ & 5 & 2 \\
\hline & & & $2.75 \rightarrow 2.80$ & & \\
\hline & & & $2.04(\times 2) \rightarrow 2.02(\times 2)$ & & \\
\hline & & & $1.60 \rightarrow 1.62$ & & \\
\hline \multirow[t]{10}{*}{ EcoRI } & $\mathrm{A} 2$ & - & $2.10 \rightarrow 2.00$ & 1 & 1 \\
\hline & & & $1.92(\times 2) \rightarrow 1.91(\times 2)$ & & \\
\hline & & & b $1.34 \rightarrow 1.38$ & & \\
\hline & & & $1.28 \rightarrow 1.30$ & & \\
\hline & & & $1.10 \rightarrow 1.05$ & & \\
\hline & & & $1.00 \rightarrow 0.97$ & & \\
\hline & $\mathrm{A} 3$ & - & $3.10 \rightarrow-$ & 5 & 2 \\
\hline & & & b $1.34 \rightarrow 1.38$ & & \\
\hline & & & $1.10 \rightarrow 1.16$ & & \\
\hline & & & g $1.00(\times 2) \rightarrow 1.03(\times 2)$ & & \\
\hline \multirow[t]{2}{*}{ HindIII } & $\mathrm{A} 2$ & - & $9.00 \rightarrow 8.80$ & 5 & 2 \\
\hline & & & $2.30 \rightarrow 2.50$ & & \\
\hline \multirow{4}{*}{ HincII } & $\mathrm{A} 2$ & - & $1.68(\times 2) \rightarrow 1.70(\times 2)$ & 1 & 1 \\
\hline & $\mathrm{A} 3$ & - & $1.78 \rightarrow 1.80$ & 4 & 2 \\
\hline & A4 & $4.75 \rightarrow 3.40+1.35$ & g $1.65(\times 2) \rightarrow 1.68(\times 2)$ & 5 & 2 \\
\hline & & & $0.96(\times 2) \rightarrow 1.00(\times 2)$ & & \\
\hline \multirow[t]{10}{*}{$A v a \mathbf{I}$} & $\mathrm{A} 2$ & e $2.80+9.20 \rightarrow 12.00$ & $5.00(\times 2) \rightarrow 5.25(\times 2)$ & 1 & 1 \\
\hline & & & $4.55 \rightarrow 4.61$ & & \\
\hline & & c $4.75 \rightarrow 4.61+X$ & $2.00(\times 2) \rightarrow 1.96(\times 2)$ & & \\
\hline & $\mathrm{A} 3$ & c $4.75 \rightarrow 4.61+X$ & $1.56 \rightarrow 1.60$ & 4 & 2 \\
\hline & & & $1.23 \rightarrow 1.20$ & & \\
\hline & & e $2.80+9.20 \rightarrow 12.00$ & d $1.89 \rightarrow 2.00$ & & \\
\hline & A4 & e $2.80+9.20 \rightarrow 12.00$ & $5.00(\times 2) \rightarrow 4.90(\times 2)$ & 5 & 2 \\
\hline & & & $3.80 \rightarrow 3.83$ & & \\
\hline & & $4.70 \rightarrow 4.10+X$ & $2.55 \rightarrow 2.50$ & & \\
\hline & & & d $1.89 \rightarrow 2.00$ & & \\
\hline \multirow[t]{8}{*}{$B g l \mathrm{II}$} & D2 & - & f $1.93 \rightarrow 1.90$ & 16 & 2 \\
\hline & & & & 19 & 2 \\
\hline & D3 & - & $\rightarrow 2.35$ & 17 & 1 \\
\hline & & & f $1.93 \rightarrow 1.90$ & & \\
\hline & & & $1.48 \rightarrow 1.51$ & & \\
\hline & & & $1.26 \rightarrow 1.22$ & & \\
\hline & & & $0.79 \rightarrow 0.70$ & & \\
\hline & & & $0.65 \rightarrow 0.61$ & & \\
\hline
\end{tabular}

$x=$ Fragment not visualized because of size. 
Table 4 Proportion of shared fragments $(F$-values, $\%)$ for five distinct cpDNA genomes ( $\mathrm{Lm}, \mathrm{Lm} 1, \mathrm{Lm} 2, \mathrm{Lm} 3, \mathrm{Lm} 4)$ observed in $P$. lanceolata from using the $A v a \mathrm{I}, B s t \mathrm{I}, B g l \mathrm{II}$, EcoRI, HindIII, and HincII enzymes (lower left) and for three distinct chloroplast genomes (MM, Mm1, Mm2) observed in P. media using BglII as the restriction enzyme (upper right)

\begin{tabular}{|c|c|c|c|c|c|c|}
\hline \multicolumn{2}{|c|}{ P. lanceolata } & \multicolumn{5}{|c|}{ P. media } \\
\hline $\begin{array}{l}\text { Accession } \\
\text { number }\end{array}$ & Genome & MM & Mm1 & $\mathrm{Mm} 2$ & & $\begin{array}{l}\text { Accession } \\
\text { number }\end{array}$ \\
\hline $1,2,3$ & LM & - & 97.8 & 88.2 & $\mathrm{MM}$ & 15,18 \\
\hline 1 & Lm1 & 91.0 & - & 92.4 & Mm1 & 16,19 \\
\hline 1 & Lm2 & 95.9 & 91.5 & - & $\mathrm{Mm} 2$ & 17 \\
\hline 4 & Lm3 & 96.1 & 90.8 & 96.1 & - & \\
\hline \multirow[t]{2}{*}{5} & $\mathrm{Lm} 4$ & 87.1 & 84.6 & 86.7 & 87.3 & \\
\hline & & LM & Lm1 & Lm2 & Lm3 & \\
\hline
\end{tabular}

Numbers (from 1 to 5 and from 15 to 19 ) refer to the accessions described in Table 1.

subspecies (Molgaard, 1976; Van Dijk \& Van Delden, 1981; Van Dijk, 1984). Moreover, plants of the two subspecies have been found to grow together at several places in which a few individuals show intermediate morphological characters, suggesting that hybridization may take place between the subspecies (Molgaard, 1976; Van Dijk \& Van Delden, 1981). Hybrid individuals between the two subspecies have also been easily obtained from experimental crosses, and most of these individuals showed intermediate morphological characters, good viability and high fertility (Molgaard, 1976; Van Dijk \& Van Delden, 1981).

As shown in the present study, the larger $(70 \mathrm{bp})$ DNA fragment present in $P$. major as compared to the cpDNA genome of $P$. pleiosperma, was also not observed in two individual plants identified morphologically as $P$. major subsp. major. These plants were from a site (namely accessions 8 and 13, near Roskilde in Denmark) where both subspecies grow together. This situation suggests that hybridization may have occurred between the subspecies and that the morphological phenotype of subsp. major may have been conferred on the two individuals by natural successive hybridization and backcrossing with individuals of subsp. major. Moreover, if, as shown by previous studies, there is essentially maternal inheritance of cpDNA in Plantago (Kirk \& Tilney-Basset, 1978; Corriveau \& Coleman, 1988 and unpublished results), individuals of subsp. pleiosperma are likely to have been the seed parents in the original hybridization event, with subsp. major being the pollen parent in the subsequent crosses. In Dutch populations, Wolff \& Schaal found three length mutations $(80,80$ and 130 bp respectively) discriminating subsp. pleiosperma from subsp. major with, in all cases, the larger fragment being present in subsp. major. It is likely that one of the two $80-\mathrm{kb}$ length mutations observed by Wolff \& Schaal (1992) corresponds to the 70-bp length mutation revealed in the present study. Furthermore, in a Dutch population, they identified several plants morphologically as subsp. pleiosperma, which showed subsp. major genes, suggesting that cpDNA introgression occurred from subsp. major into subsp. pleiosperma, i.e. in the reverse direction to that observed in the Danish population. This result suggests that reciprocal introgressions are likely to have occurred between both subspecies; a specific direction of crosses being favoured in a particular place by local circumstances.

In a previous study, Molgaard (1976) suggested that subsp. pleiosperma was present during the late glacial period in Western Europe whereas subsp. major was introduced later, as a weed, from Eastern Europe. According to this hypothesis, $P$. major may have been derived from $P$. pleiosperma by several cpDNA insertions.

\section{Intraspecific cpDNA variation}

General trends. Substantial variation was observed in $P$. media among the several geographical accessions, and a still higher rate of variation occurred in $P$. lanceolata, both among and within populations, whereas no cpDNA variation was observed within each of the two subspecies of $P$. major. Data for $P$. coronopus were not sufficient to permit comparison with the other species. Similarly, Wolff \& Schall (1992) did not find cpDNA 
variation within the two subspecies of $P$. major in the Dutch populations except where introgression between the subspecies was assumed to occur. However, additional cpDNA mutations were observed to be specific to the whole plants from the American populations.

In the present study, in both $P$. lanceolata and $P$. media, 88 and 100 per cent, respectively, of the cpDNA variation seems to be due to length mutations rather than to site mutations. Similar observations have been made on species in several other genera: e.g. Pisum (Palmer et al., 1985), Euoenothera (Gordon et al., 1982), Triticum and Aegilops (Bowman et al., 1983), Glycine (Apuya et al., 1988), and Oryza (McCouch et al., 1989). However, in other genera, e.g. Nicotiana (Kung et al., 1982) and Linum (Coates \& Cullis, 1987), restriction site changes have been reported to be the most common type of cpDNA mutation.

Plantago lanceolata. In $P$. lanceolata, the cosmopolitan majority genotype (LM) (which occurs in several sites of the Netherlands and in Montpellier) and the two minority genotypes ( $\mathrm{Lm} 1$ and $\mathrm{Lm} 2$ also found in Montpellier where the sample size was larger than in the other sites), show close restriction patterns which are very distinct from the patterns observed for plants from Sweden (Lm3) and more specifically those from Poland (Lm4). This supports previous reports based on isozyme analysis (e.g. Van Dijk et al., 1988) which indicated that $P$. lanceolata may have been introduced to Western Europe along with agricultural crops, roughly 6000 years ago.

Plantago media. In $P$. media, slight differentiation was observed among the three genotypes distinguished. The diploid and the tetraploid plants, from sites 19 and 16 respectively, showed exactly the same cpDNA genotype (Mm1) which seems to be specific to the Pyrenees. This result constitutes further evidence for autopolyploidy in $P$. media, as documented by Van Dijk \& Van Delden (1990) from a study of morphological and enzyme variation. In $P$. media, two diploid and two tetraploid plants from the Pyrenees were also analysed by Wolff \& Schaal (1992). Four restriction site polymorphisms observed for three enzymes not used in the present study were found between the two cytotypes, suggesting that the divergence between the diploids and the tetraploids is not of recent origin. In the present study, the tetraploids were collected in the single limited area where plants of both ploidy levels grow in mixture (Van Dijk \& Hartog, 1988) whereas the tetraploids studied by Wolff \& Schaal (1992) were collected in another area where only tetraploid plants have been observed (Van Dijk \& Hartog, 1988). A lack of consistency between the results of the two studies may therefore reveal the occurrence (in the Pyrenees) of tetraploids from two distinct origins. The present geographical distribution of the diploids comprises several distinct regions, the Pyrenees, South Eastern Europe and the Eastern part of Russia, whereas the tetraploids are widely distributed throughout Europe and Western Asia (Van Dijk \& Hartog, 1988). In $P$. media, high genetic differentiation, based on enzyme polymorphism, was observed between the diploids from the Soviet Union and those from the Pyrenees (Van Dijk \& Van Delden, 1990). This, combined with results from cpDNA analysis, suggests multiple origins of the autotetraploids, one of which occurred in the Pyrenees, rather than differentiation within tetraploids subsequent to a single autopolyploidization event. However, more populations of both cytotypes need to be studied from several areas to provide decisive evidence for multiple origins of polyploids in $P$. media. The multiple origins of autotetraploids have been shown previously in several other species, e.g. Tolmiea menziezii (Soltis et al., 1989a), Heuchera micrantha (Soltis et al., 1989b) and Heuchera grossulariifolia (Wolff et al., 1990) from the study of cpDNA variation.

\section{Chloroplast DNA variation and the mating system}

In previous studies, relationships between the mating system, phenotypic plasticity and genetic structure, measured using polymorphism at enzyme loci, have been established in several Plantago species. P. lanceolata, a self-incompatible, gynodioecious species, showed considerable phenotypic plasticity and a high genetic diversity within populations but low differentiation among populations. In contrast, lower genetic diversity and significant population differentiation was observed in the self-compatible species, $P$. major (Van Dijk et al., 1988; Wolff, 1988). The self-incompatible hermaphrodite species, $P$. media, was less variable morphologically than the above two species but the diploids, as well as the tetraploids, possessed substantial allelic diversity with a rather low rate of local differentiation (Van Dijk \& Van Delden, 1990). Moreover, Wolff \& Schaal have reported that 'the inbreeding $P$. major populations behave like separate nearly invariable strains with extremely low cpDNA variability'. In this species, changes in cpDNA were thus restricted to between populations of the two subspecies and to between American and Dutch (maybe European) populations. In the latter case, the change may be attributed to founding effects.

In the present study, cpDNA polymorphism is observed exclusively in the two outcrossing species of Plantago suggesting that there might be some connection between characteristics of the breeding system, 
which are responsible for nuclear gene recombination, and chloroplast genome variation which shows cytoplasmic, uniparental inheritance. In $P$. lanceolata, part of the variation may be due to the contribution of cpDNA to male sterility as has been shown in tobacco (Frankel et al., 1979), cotton (Galau \& Wilkins, 1989) and sorghum (Chen et al., 1990). Furthermore, in the two outcrossing species of Plantago, high gene flow and multiple combinations of nucleo-cytoplasmic genomes may favour a higher cpDNA polymorphism. Distinct minority patterns could subsequently be fixed as local majority patterns in different regions. Such a hypothesis has already been put forward to explain the high cpDNA variability observed in hybrid zones between related taxa (e.g. Govindaraju et al., 1989).

\section{Acknowledgements}

This research was supported by a grant obtained from the European Network of Population Biology. We gratefully acknowledge Drs Symonides, Prentice, Van Dijk and Van Herk for collecting plant material, Dr A. Dally for technical support and Dr J. Thompson and Professor Y. Linhart for making useful suggestions on how to improve the manuscript.

\section{References}

ALEXANDER, H. M. AND WULFF, R. D. 1985. Experimental ecological genetics in Plantago. X. The effects of maternal temperature on seed and seedling characters in Plantago lanceolata. J. Ecol., 73, 271-282.

ANTONOVICS, J. AND PRIMACK, R. B. 1982. Experimental ecological genetics in Plantago lanceolata. J. Ecol., 70, 55-75.

APUYA, N. F., FRAIER, B. L., KEIM, P., JILL-ROTH, E. AND LARK, K. G. 1988. Restriction fragment length polymorphism as genetic markers in soy bean Glycine max (L.) Merrill. Theor. Appl. Genet., 75, 889-901.

BANKS, J. A. AND BIRKY, C. w. 1985. Chloroplast DNA diversity is low in a wild plant, Lupinus texensis. Proc. Natl. Acad. Sci., U.S.A., 82, 6950-6954.

Bos, M., STEEN, R. AND HARMENS, H. 1985. Protogyny in Plantago lanceolata populations: an adaptation to pollination by wind. In: Jacquard, P. Heim, G. and Antonovics, J. (eds) Genetic Differentiation and Dispersal in Plants, SpringerVerlag, Berlin, pp. 327-338

BOWMAN, C. M., BONNARD, G. AND DYER, T. A. 1983. Chloroplast DNA variation between species of Triticum and Aegilops. Location of the variation on the chloroplast genome and its relevance to the inheritance and classification of cytoplasm. Theor. Appl. Genet., 65, 247-262.

CHEN, Z., LIANG, G. H., MUTHUKRISHNAN, S. AND KOFOLD, K. D. 1990. Chloroplast DNA polymorphism in fertile and malesterile cytoplasms of sorghum (Sorghum bicolor (L.) Moench). Theor. Appl. Genet, 80, 727-731.

CLEGG, M. T., BROWN, A. D. H. AND WHITFIELD, P. R. 1984. Chloro- plast DNA diversity in wild and cultivated barley: implications for genetic conservation. Genet. Res., 43, 339-343.

COATES, D. AND CULLIS, C. A. 1987. Chloroplast DNA variability among Linum species. Am. J. Bot., 74, 260-268.

CORRIVEAU, J. L. AND COLEMAN, A. w. 1988. Rapid screening methods to detect potential biparental inheritance of plastid DNA and results for over 200 angiosperm species. Am. J. Bot., 75, 1443-1458.

DALLY, A. M. AND SECOND, G. 1989. Chloroplast DNA isolation from higher plants: an improved non-aqueous method. Plant Mol. Biol. Rep., 7, 135-143.

DOEBLEY, J., RENFROE, W. AND BLANTON, A. 1987. Restriction site variation in the Zea genome. Genetics, 17, 139-147.

ENGLer, A. 1937. Das Pflanzenreich IV. 269 (102 Heft) Plantaginaceae von Robert Pilger. Wihelm Engelmann, Leipzig.

FELSENSTEIN, J. 1985. Confidence limits on phylogenies: an approach using the bootstrap. Evolution, 39, 783-791.

FELSENSTEIN, J. 1987. PHYLIP, ver. 3.0 [computer software and manual] (published by author). Dept. of Genetics, University of Washington, Seattle, WA. 98195, U.S.A.

FRANKEL, R., SCOWCROFT, W. R. AND WHITFIELD, P. R. 1979. Chloroplast DNA variation in isonuclear male-sterile lines of Nicotiana. Mol. Gen. Genet., 169, 129-135.

GALAU, G. A., AND WILKINS, T. A. 1989. Alloplastic male sterility in A D allotetraploid Gossypium hirsutum upon replacement of its resident A cytoplasm with that of D species $G$. harknesii. Theor. Appl. Genet., 78, 23-30.

GORDON, K. H. J., GROUSE, E. J., BOHNERT, H. J. AND HERMANN, R. G. 1982. Physical mapping of differences in chloroplast DNA of the five wild-type plastomes in Oenothera subsect. Euoenothera. Theor. Appl. Genet., 61, 373-384.

GOVINDARAJU, D, R., DANCIK, B. P. AND WAGNER, D. B. 1989. Novel chloroplast DNA polymorphism in a sympatric region of two pines. J. Evol. Biol., 2, 49-59.

HARRIS, S. A. AND INGRAM, R. 1991. Chloroplast DNA and biosystematics: The effects of intraspecific diversity and plastid transmission. Taxon, 40, 393-412.

KIRK, G. T, O. AND TILNEY-BASSETT, R. A. E. 1978. The Plastids. Elsevier, Amsterdam.

KUNG, S. D., ZHU, Y. S. AND SHEN, G. F. 1982. Nicotiana chloroplast genome III. Chloroplast DNA evolution. Theor. Appl. Genet., 61, 73-79.

LEHVÄsLAiHo, H., SAURA, A. AND LOKKI, J. 1987. Chloroplast DNA variation in the grass tribe Festuceae. Theor. Appl. Genet., 74, 298-302.

LUMARET, R., BoWman, C. M. AND DYeR, T. A. 1989. Autopolyploidy in Dactylis glomerata L. Further evidence from studies of chloroplast DNA variation. Theor. Appl. Genet., 78, 393-399.

McCOUGH, S. R., KOCHERT, G., YU, Z. H., WANG, Z. Y., KHUSH, G. S., COFFMAN, W. R. AND TANKSLEY, S. D. 1989. Molecular mapping of rice chromosomes. Theor. Appl. Genet., 76, 815-829.

MOlgAARD, P. 1976. Plantago major ssp. major and ssp. pleiosperma. Morphology, biology and ecology in Denmark. Bot. Tisskrift bd., 71, 31-56.

NEI, M. AND LI, W. H. 1979. Mathematical model for studying genetic variation in terms of restriction endonucleases. Proc. Natl. Acad. Sci., U.S.A., 76, 5269-5273. 
PALMER, J. D. 1986. Chloroplast DNA and phylogenetic relationships. In: Dutta, S. (ed.) DNA Systematics II, CRC Press, Inc., Boca Raton, FL, pp. 63-80.

PALMER, J. D. 1987. Chloroplast DNA and biosystematic uses of chloroplast DNA variation. Am. Nat., 130 (suppl), 6-29.

PALMER, J. D., JORGENSEN, R. A. AND THOMPSON, W. F. 1985. Chloroplast DNA variation and evolution in Pisum: patterns of change and phylogenetic analysis. Genetics, 109, 195-213.

PILLAY, M. AND HILU, K. 1990. Chloroplast DNA variation in diploid and polyploid species of Bromus (Poaceae) subgenera Festucaria and Ceratochloa. Theor. Appl. Genet., 80, 326-332.

RAHN, K. 1954. Experimental and cytological studies in Plantago media. Bot. Tidskr., 31, 300-307.

RAHN, K. 1957. Chromosome numbers in Plantago. Bot. Tidskr., 53, 369-378.

Ross, M. D 1970. Breeding systems in Plantago. Heredity, 25, 129-133.

Ross, M. D. 1973. Inheritance of self-incompatibility in Plantago lanceolata. Heredity, 30, 169-176.

ROUWENDAL, G. J. A., VAN DAMME, J. M. M. AND WESSELS, J. G. H. 1987. Cytoplasmic male sterility in Plantago lanceolata L.: differences between male-sterile cytoplasms at the DNA and RNA-level. Theor. Appl. Genet., 75, 59-65.

SAGAR, G. R. AND HARPER, J. L. 1964. Biological flora of the British isles. Plantago major L., $P$. media L., and $P$. lanceolata L. J. Ecol., 52, 189-221.

SANDBRINK, J. M., GEURTS, L. J. L. M. T., GADELLA, W. J. AND VAN BREDERODE, J. 1989. Chloroplast DNA variation in Silene section Elisanthe demonstrates Silene noctiflora $\mathbf{L}$. is not properly classified. Biochem. Syst. Ecol., 17, 539-549.

SANDBRINK, J. M., VAN BRUGGEN, A. C. AND VAN BREDERODE, J. 1990. Patterns of intraspecific chloroplast DNA variation in species of Silene section Elisanthe. Biochem. Syst. Ecol., 18, 233-238.

SANDBRINK, J. M. AND VAN BREDERODE, J. 1992a. Different approaches to analysis of restriction fragment patterns of chloroplast DNA and phylogenetic relationships in Silene section Siphonomorpha Otth. (Caryophyllaceae). Accepted in Biochem. Syst. Ecol.

SANDBRINK, J. M., VAN HAM, R. E. H. J. AND VAN BREDERODE, J. 1992b. Chloroplast DNA and morphological variation in the fern genus Platycerium (Polypodiaceae). Accepted in Fern Gaz.

SOlTIS, D. E., SOlTIS, P. S., RANKER, T. A. AND NESS, B. D. 1989a. Chloroplast DNA variation in a wild plant, Tolmiae menziesii. Genetics, 121, 819--826.

SOLTiS, D. E., SOLTIS, P. S. AND NESS, B. D. 1989b. Chloroplast DNA variation and multiple origins of autopolyploidy in Heuchera micrantha (Saxifragaceae). Evolution, 43, 650-656.

SORENG, R. J. 1990. Chloroplast DNA phylogenetics and biogeography in reticulating groups: study in Poa (Poaceae). Am. J. Bot., 77, 1383-1400.

SYTSMA, K. J. AND SCHAAL, B. A. 1985. Phylogenetics of the Lisianthius skinneri (Gentianaceae) species complex in
Panama utilizing DNA restriction fragment analysis. Evolution, 39, 594-608.

TIMOTHY, D. H., LEVINGS, C. S., PRING, D. R., CONDE, M. F. AND KERMICLE, J. L. 1979. Organelle DNA variation and systematic relationships in the genus Zea: teosinte. Proc. Natl. Acad. Sci., U.S.A., 76, 4220-4224.

TUtin, T. G. AND WEBB, D. A. 1976. Flora Europaea, Vol. 4, Cambridge University Press, Cambridge.

VAN DAMME, J. M. M. 1983. Gynodioecy in Plantago lanceolata L. II Inheritance of three male sterility types. Heredity, 50, 253-273.

VAN DAMME, J. M. M. 1986. Gynodioecy in Plantago lanceolata L. V. Frequencies and spatial distribution of nuclear and cytoplasmic genes. Heredity, 56, 355-364.

VAN DAMME, J. M. M. AND VAN DELDEN, w. 1982. Gynodioecy in Plantago lanceolata L. I. Polymorphism for plasmon type. Heredity, 49, 303-318.

VAN DAMME, J. M. M. AND VAN DELDEN, w. 1984. Gynodioecy in Plantago lanceolata L. IV. Fitness components of sex types in different life cycle stages. Evolution, 38, 1326-1336.

VAN DIJK, H. 1984. Genetic variability in Plantago species in relation to their ecology. 2. Quantitative characters and allozyme loci in P. major. Theor. Appl. Genet., 68, 43-52.

VAN DIJK, H. 1985. Allozyme genetics, self-incompatibility and male-sterility in Plantago lanceolata. Heredity, 54, 53-63.

VAN DIJK, H. AND VAN DELDEN, w. 1981. Genetic variability in Plantago species in relation to their ecology. 1. Genetic analysis of the allozyme variation in Plantago major subspecies. Theor. Appl. Genet., 60, 285-290.

VAN DIJK, H., WOLFF, K. AND DE VRIES, A. 1988. Genetic variability in Plantago species in relation to their ecology. 3. Structure of populations of $P$. major, $P$. lanceolata and $P$. coronopus. Theor. Appl. Genet., 75, 518-528.

VAN DIJK, P. AND HARTOG, M. 1988. The geographical distribution of cytotypes of Plantago media in the Pyrenees and its importance for the study of the evolutionary significance of polyploidization in plants. Documents d'Ecologie Pyrénéenne, 5, 121-131.

VAN DIJK, P. AND VAN DELDEN, w. 1990. Evidence for autopolyploidy in Plantago media and comparisons between natural and artificial cytotypes concerning cell size and fertility. Heredity, 65, 349-357.

VAN GROENENDAEL, J. M. M. 1986. Life history characteristics of two cytotypes of Plantago lanceolata L. Acta Bot. Neerl., 35, $71-86$.

WOLF, P. G., SOLTIS, D. E. AND SOLTIS, P. S. 1990. Chloroplast DNA and allozymic variation in diploid and autotetraploid Heuchera grossulariifolia (Saxifragaceae). Am. J. Bot., 77, 232-244.

WOLFF, K. 1988. Natural selection in Plantago species: a genetical analysis of ecological relevant morphological variability. Thesis, University of Groningen, The Netherlands.

WOLFF, K., FRISO, B. AND VAN DAMME, J. M. M. 1988. Outcrossing rates and male sterility in natural populations of Plantago coronopus. Theor. Appl. Genet., 76, 190-196.

WOLFF, K. AND SCHAAL, B. 1992. Chloroplast DNA variation within and among five Plantago species. J. Evol. Biol., 5, 325-344. 